\title{
Service Quality, Relationship Quality and Customer Loyalty (Case Study: Banking Industry in Iran)
}

\author{
Leila Rahmani-Nejad1*, Zahra Firoozbakht², Amin Taghipoor ${ }^{3}$ \\ ${ }^{1}$ Faculty of Accounting and Management, School of Financial Management, University of Sistan and \\ Baluchestan, Zahedan, Iran \\ ${ }^{2}$ Department of Business Administration, Karaj Payamnur University, Tehran, Iran \\ ${ }^{3}$ Faculty of Technology \& Engineering, School of Civil Engineering Construction Engineering Management, \\ Islamic Azad University of Science and Research of Isfahan, Isfahan, Iran \\ Email: ${ }^{*}$ sh.hosseini81@yahoo.com
}

Received 12 February 2014; revised 16 March 2014; accepted 24 March 2014

Copyright ( 2014 by authors and Scientific Research Publishing Inc.

This work is licensed under the Creative Commons Attribution International License (CC BY).

http://creativecommons.org/licenses/by/4.0/

(c) (i) Open Access

\begin{abstract}
Customer loyalty has two meanings: long-term and short-term loyalty. Customers with long-term loyalty do not easily switch to other service providers, while customers with short-term loyalty defect more easily when offered a perceived better alternative. With regard to the importance of customers in banking industry, this research explores how relationship quality and commitment and mental image influence long-term loyalty. Relationship quality consists of two aspects: satisfaction and trust. So, along with how the above mentioned variables from loyalty in a bank environment, the managers of the branches of private banks are given the chance to design and perform effective and proper strategies leading to customer loyalty. The statistical populations of the research are the customers of private banks and the data was collected using the questionnaire and also the data has been analyzed using SPSS software. The results of the research show the positive effect of the abovementioned variables on loyalty.
\end{abstract}

\section{Keywords}

Customer Loyalty; Service Quality; Relationship Quality; Commitment; Mental Image

\section{Introduction}

Customer loyalty is important to banks and service firms because customer defections "can have more to do

${ }^{*}$ Corresponding author. 
with a service company's profits than scale, market share, unit costs, and many other factors usually associated with competitive advantage”. Banks serving private customers seek to reduce defections by building relationship Loyalty is an emotional relationship between the customers and the company. Therefore, loyalty is measured by the customer relationship strength. In competitive, complex \& dynamic bank industry setting, only a small distinction in service providing, will cause a great transformation. Traditional banks, according to the principals of Relationship Marketing that consider the customers loyalty as its main goal, are going to be changed in to customer-based ones. In such dynamic setting, producing \& setting strategies, which result in making customers loyal, is so important [1]. Trust and satisfaction both are related to both behavioral and attitudinal loyalty. Satisfaction is positively related to repurchase intention and customer loyalty [2]. Additional work by [3], finds that perceptions of commitment can lead to word-of-mouth communication, an aspect of attitudinal loyalty, and can result in future purchase intentions, an aspect of behavioral loyalty [4].

\section{Theoretical Background}

Customer loyalty is an important objective for strategic marketing planning and represents an important basis for developing a sustainable competitive advantage. Some researchers state that a positive relationship exists between loyalty of customers and performance of companies. Customer loyalty leads to increase business value and keeps business costs low as well. Increase in value and saving money mean lower time when companies seek for new customers. Many definitions about loyalty have two points in common; that is, behavioural aspect and attitudinal aspect [5]. Behavioral loyalty is customer's repeated transaction and researches usually measure this aspect by observational techniques. Attitudinal loyalty has both positive effect on the relationship continuance, and the tendency to continue to remain in the relationship [6]. Loyalty is a dedication on the part of the buyer to maintain a relationship and a devotion to buy the product or service repeatedly. Loyalty thus has a behavioral component which suggests a repurchase intention but also includes an attitudinal component which is based on preferences and impression of the partner. Trust can create benefits for the customers by decreasing transaction cost ultimately fostering customer loyalty to the relationship [7]. Loyalty has been defined as "a deeply held commitment to rebury or repatronize a preferred product/service consistently in the future”.

\subsection{Loyalty and Satisfaction}

Customer satisfaction is an overall attitude formed based on the experience after customers purchase a product or use a ser-vice [8]. It is a reflection of being content with such a product or a service. Satisfaction is the assessment of the experience of interacting with a service provider up to the present time, and is used by customers to predict future experience [9]. Satisfaction is a broad feeling, which is affected by service quality, product quality, price, and contextual and personal factors [10]. Satisfaction is one of the antecedents of customer loyalty. satisfaction positively affects customer loyalty [11]. Although the reason that customers remain loyal may not always be satisfaction [12], it is safe to say that satisfied customers are more loyal.

\subsection{Loyalty and Trust}

Trust has been studied extensively in literature. Trust has been defined as one party believing that the other party wills fulfill his or her needs. In terms of services, trust is the belief held by a customer that the service provider will provide the service that meets customer needs. A more general definition of trust is that a party has confidence in the honesty and reliability of his partner.This definition can be applied in different contexts, including exchanges of goods and services. Trust consists of two aspects: Perceived credibility and benevolence [13]. There are two levels of trust, at the first level, the customer trusts one particular sales representative while at the second level, the customer trusts the institution [14]. Trust is an important mediating factor between customer behavior before and after purchasing a product which can lead to long-term loyalty and strengthen the relationship between the two parties [15]. As with loyalty, trust is a special psychological state that can only occur in certain relationships. When a customer trusts an organization, he or she has the confidence in service quality and product quality of the organization. Customers who trust an organization are more than likely to be loyal to the company. [16] point out that the precondition of customer loyalty is customer trust. In prior research, trust has been conceptualized as antecedent of satisfaction [17]. 


\subsection{Loyalty and Commitment}

Commitment is a pledge of continuity between relational partners [18] [19] points out that It may also be viewed as the attachment that one party perceives towards another party in a situation. At its core, commitment is an attitude towards the act of maintaining a relationship with a partner. Over the past years of relationship marketing scholarship, our understanding of commitment has significantly expanded. From a construct that had a limited definition, it is now regarded as a complex construct that includes multiple components. Many researchers in marketing have borrowed from the organizational behavior literature where there is a rich tradition of research on the organizational commitment construct.

\subsection{Loyalty and Mental Image}

An organization's image is an important variable that positively or negatively influences marketing activities. Image is considered to have the ability to influence customers' perception of the goods and services offered. Thus, image will have an impact on customers' buying behavior. Service literature identifies a number of factors that reflects image in the customer's mind. Image is considered to influence customers' minds through the combined effects of advertising, public relations, physical image, word-of-mouth, and their actual experiences with the goods and services. Similarly, [20], using numerous researches on service organizations, found that service quality was the single most important determinant of image. Thus, a customer's experience with the products and services is considered to be the most important factor that influences his/her mind in regard to image. Heung et al. found image to be an important factors, and to maintain a relatively high score rating among loyal customers. According to Mazanec image is positively associated with customer satisfaction and customer preference (a dimension of customer loyalty).

\subsection{Relationship Quality}

To create long-lasting customer relationships, relationship marketing, include marketing activities that attract, develop, maintain, and enhance customer relationships, has been utilized in a wide variety of industries. Customers care about the relationship as a whole and judge the relationship using past experience, expectations, predictions, goals, and desires. Relationship quality has been positively linked to customer loyalty. There is no unified definition of relationship quality. Relationship quality has been conceptualized as a construct consisting of several components. These components include satisfaction, trust, commitment, and overall quality among others [11]. In the prior studies, satisfaction, trust are the most examined aspects of relationship quality [21].

\subsection{Service Quality}

Service managers need to understand how perceptions of their performance on service quality dimensions influence levels of customer satisfaction. The literature shows positive effects of customer satisfaction on such desirable outcomes as repeat purchase [22], retention, loyalty [23], retailer sales performance [24], and profitability [25]. Discussion of service quality has resulted in the realization of the intangible, heterogeneous, and inseparable nature of the concept [26]. Thus it is hard to measure it with the same measurement for product quality. Quite a few conceptualizations and measurements of service quality may be found in the literature. For example, it has been defined as consisting of two aspects :technical quality and functional quality [27]. Service quality is also defined as the difference between customer expectation and the perception of service quality. Parasuraman et al. provided a list of their focus group studies with service providers and customers: access, communication, courtesy, competence, credibility, reliability, responsiveness, security, understanding and tangibles. In a later article they added that: "although the relative importance of the categories would vary from one service industry to the next, we believe the determinants of service quality in most (if not all) consumer service industries are included in this list.” They then used the five dimensions tangible, reliability, responsiveness, assurance and empathy-as the basis for their service quality measurement instrument, SERVQUAL. However, some argue that measuring service quality using SERVQUAL, which is based on performance-minus-expectation (or gaps), is inappropriate and suggest that SERVPERE, which is performance-only measurement, is a better method [28]. A third conceptualization of service quality includes interaction quality, physical environment quality, and outcome quality [29]. Interaction quality includes attitude, behavior, and expertise. Physical environment quality includes ambient conditions, design, and social factors. Outcome quality includes waiting time, tangibles, and 
valence. In this study, service quality is defined as the whole service quality perceived by customers after using the service. Service quality is very important to customer satisfaction and trust. It is also one of the often studied antecedents of relationship quality. Service quality represents basic customer expectations, thus, a hygiene factor. In a study of service quality in banking, hospitals, and photo development, service quality was found to have a positive effect on relationship quality, which includes satisfaction and trust [30]. Service quality is an important factor affecting customer satisfaction [31]. The increase in customer's perceptions of service quality will influence aspects of relationship quality such as satisfaction and trust [32]. In studying the 3C (computer, communication, and consumer electronic) retail industry in Taiwan, service quality has been shown to have a significant impact on trust [33].

\section{The Conceptual Model of the Research}

In this research, a model that investigates the effects of relationship quality and mental image and commitment on customer loyalty.Both relational qualities, including satisfaction and trust and mental image and commitment have significant effects on customer loyalty (Figure 1).

\section{Statistical Hypothesis}

H1: satisfaction has positive effect on customer loyalty.

H2: trust has positive effect on customer loyalty.

H3: commitment has positive effect on customer loyalty.

H4: Mental image has positive effect on customer Loyalty.

According to the table above, the mean and $\mathrm{T}$ of satisfaction, trust, commitment, mental image:

$(4.54,4.06,3.87,4.18)$ and $(33.16,29.41,28.09,31.78)$ respectively. Since the calculated $T$ with the freedom degree of 159 is significant at the level of 99 percent $(\mathrm{P}<0.01)$ and the mean of satisfaction, trust, commitment, mental image larger than the T. value (3), so, The results of the research show the positive effect of the abovementioned variables on customer loyalty (Table 1 ).

Now we can come to the conclusion research: Satisfaction has most amount of positive effect on customer loyalty. The variable of mental image is of most positive effect after satisfaction and following these variables, trust, and commitment are most effective on customer loyalty.

H5: service quality has significantly positive or negative effect on satisfaction.

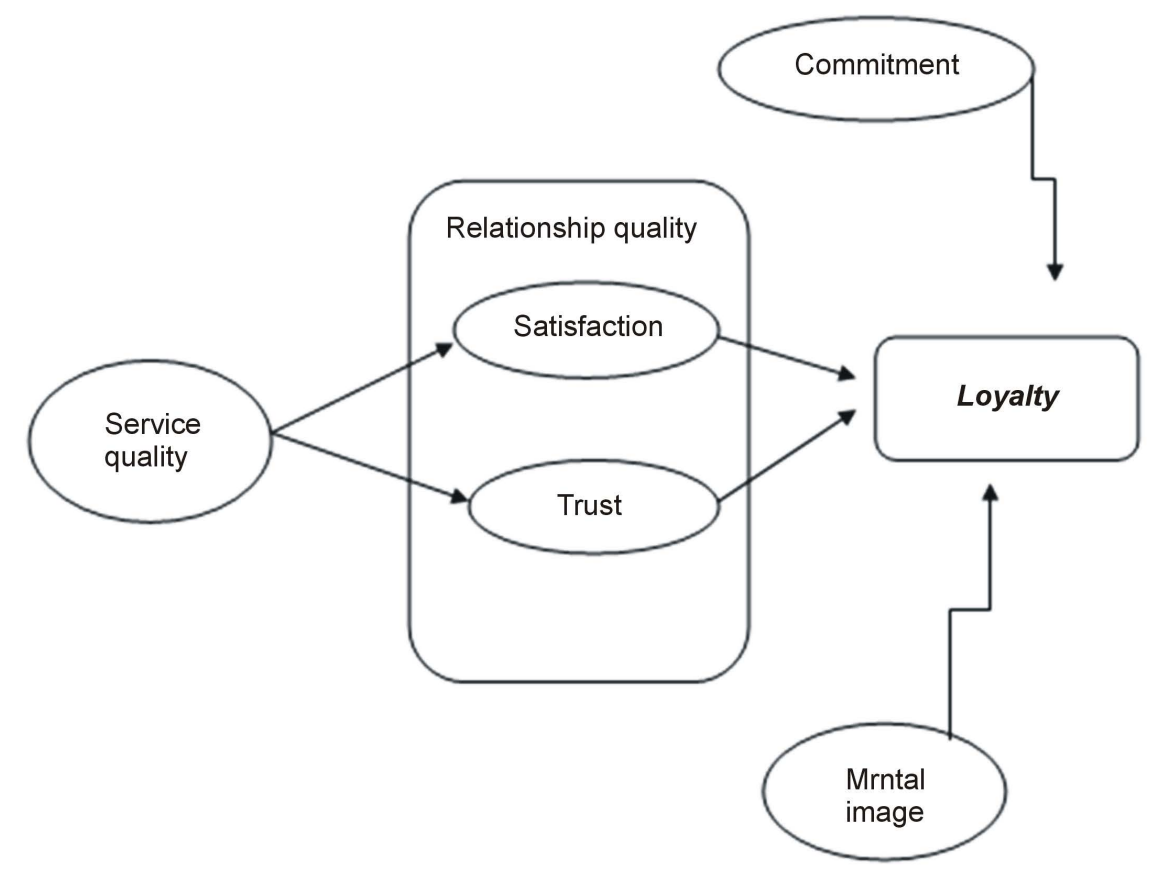

Figure 1. Conceptual model of research. 
Table 1. Statistical analysis.

\begin{tabular}{cccccc}
\hline & \multicolumn{5}{c}{ T. value = } \\
Variable & $\mathrm{N}$ & $\mathrm{T}$ & Mean & Sig & Rank of mean \\
\hline Satisfaction & 160 & 33.16 & 4.54 & 0.001 & 1 \\
Trust & 160 & 29.41 & 4.06 & 0.001 & 3 \\
Commitment & 160 & 28.09 & 3.87 & 0.001 & 4 \\
Mental image & 160 & 31.76 & 4.18 & 0.001 & 2 \\
\hline
\end{tabular}

According to Table 2, the mean and standard deviation of service quality are (19.63) and (2.54) respectively. Since the calculated $t$ (8.98) with the freedom degree of 159 is significant at the level of99 percent $(\mathrm{P}<0.01)$ and the mean of service quality (19.63) is larger than the mean of the norm of the questions (9), service quality has positive effect on satisfaction (Table 2).

H6: service quality has significantly positive or negative effect on trust.

According to Table 3, the mean and standard deviation of service quality are (17.65) and (1.47) respectively. Since the calculated t (6.67) with the freedom degree of 159 is significant at the level of 99 percent $(\mathrm{P}<0.01)$ and the mean of service quality (17.65) is larger than the mean of the norm of the questions concerning the service quality of the questionnaire (9), service quality has positive effect on trust (Table 3).

\section{Discussion}

The statistical populations of the research are the customers of private banks and the data was collected using the questionnaire and also the data has been analyzed using SPSS software. Validity of the study has been taken based on the forms and criteria of the literature and experts. Reliability of the questionnaire has been calculated through cronbach alpha. The reliability \% (79) show that questionnaire has reliability. In this research, a model that investigates the effects of relationship quality and mental image and commitment on customer loyalty.Both relational qualities, including satisfaction and trust and mental image and commitment have significant effects on customer loyalty. In our study satisfaction is more critical to customer loyalty in private banks. This approach provides a complete and detailed way to study factors relevant and of interest to marketing scholars. Service quality is found to be an important factor to both satisfaction and trust in this study, which is in consistent with prior research. It is still true in banks that improving service quality brings the benefits of increased customer satisfaction and trust. Service providers should really consider ways to improve their services in order to maintain the basic strength to compete.

\section{Conclusions}

In this research, the hypotheses based on the literature review were formulated. Now we can come to the conclusion based on the conducted research: Satisfaction with the bank has the most amount of positive effect on customer loyalty in service business organization the variable of mental image is of most positive effect after satisfaction and following this variable, trust and commitment are most effective on customer loyalty respectively. We also concluded that the effect of the quality of services on satisfaction is greater than its effect on trust. In this research, we also come as a result, the supervisors and senior managers of private banks can increase customer' level of loyalty by increase level of satisfaction, standardizing their bank services, attempting to submit services of higher quality to customers and being placed in a position compared to the ideal situation of customers' expectations. They also can generate a positive mental image in customers as well as their trust to the bank by decreasing their experts' errors and mistakes, respectful treatment of the personnel with customers and increasing their personnel's specific level. With regard to the significance of customer and his/her significant position in the equivalences of the organization and the existing competitive environment, it is necessary to consider the customer's needs and benefits in the organization. Also submitting helpful and true information to customers by the bank and providing information about the new services of the organization are of great significance in customer satisfaction and attracting his/her trust. Also according to many experimental researches, there is a direct relationship between the satisfaction of organization personnel and that of customers. 
Table 2. Statistical analysis.

\begin{tabular}{cccccccc}
\hline Variables & $\mathrm{N}$ & Mean & $\mathrm{SD}$ & $\mathrm{t}$ & $\mathrm{df}$ & Value. T & Significant level \\
\hline Service quality & 160 & 19.63 & 2.54 & 8.98 & 159 & 9 & 0.001 \\
\hline
\end{tabular}

Table 3. Statistical analysis.

\begin{tabular}{cccccccc}
\hline Variables & $\mathrm{N}$ & Mean & $\mathrm{SD}$ & $\mathrm{t}$ & $\mathrm{df}$ & Value. T & Significant level \\
\hline Service quality & 160 & 17.65 & 1.47 & 6.67 & 159 & 9 & 0.001 \\
\hline
\end{tabular}

The personnel who are in direct contact with customers are at a position that can get aware of customers' needs and wants and respond them properly. Satisfied personnel and solve the problems by having positive contact with customers. And it can be claimed that the personnel who are satisfied with their job have enough energy to empathize with customer. In this respect, we could recommend that the following be done:

To make use of the standards of quality known to everyone and to constantly assess the frequency of their usage: Nowadays, the role of the quality of the services in gaining the customer satisfaction is known to everyone. The higher quality the services enjoy, the more will be the customer satisfaction and thus their loyalty to the organization. To achieve this important factor, it is essential to constantly assess the quality of the services.

Teaching the different ways through which the staff could properly communicate with customers by holding related seminars: The staff needs to be trained to be able to communicate properly and efficiently with the customers. The organization needs to consult different experts and improve the staff's abilities in communicating with customers by having academic seminars related to this field.

The use of modern communication technology to achieve the customer satisfaction: Among the factors concerning the customer satisfaction and trust we can refer to giving useful and proper information to them through banks as well as informing them about the new technologies of the organization. To achieve this we could use technologies to help the organization.

\section{References}

[1] Beerli, A., Martin, J.D. and Quintana, A. (2004) A Model of Customer Loyalty in the Retail Banki Market. European Journal of Marketing, 38, 253-275. http://dx.doi.org/10.1108/03090560410511221

[2] Bolton, R.N. (1998) A Dynamic Model of Duration of the Customer's Relationship with a Continuous Service Provider: The Role of Satisfaction. Marketing Science, 17, 45-65.

[3] Dick, A.S. and Basu, K. (1994) Customer Loyalty: Toward Anintegrated Conceptual Framework. Journal of the Academy of Marketing Science, 22, 99-113.

[4] Fullerton, G. (2003) When Does Commitment Lead to Loyalty? Journal of Service Research, 5, 333-344.

[5] Oliver, R.L. (1999) Whence Consumer Loyalty? Journal of Marketing, 63, 33-44. http://dx.doi.org/10.2307/1252099

[6] Morgan, R. and Hunt, S. (1994) The Commitment-Trust Theory of Relationship Marketing. Journal of Marketing, 58, 20-38.

[7] Garbarino, E. and Johnson, M.S. (1999) The Different Roles of Satisfaction, Trust, and Commitment in Customer Relationships. Journal of Marketing, 63, 70-87.

[8] Fornell, C. (1992) A National Customer Satisfaction Barometer: The Swedish Experience. Journal of Marketing, 56, 6-21.

[9] Ruyter, K.D. and Wetzels, M.G.M. (2000) The Impact of Perceived Listening Behavior in Voice-to-Voice Service Encounters. Journal of Service Research, 2, 276-284. http://dx.doi.org/10.1177/109467050023005

[10] Zeithaml, V.A. and Bitner, M.J. (2000) Services Marketing: Integrating Customer Focus across the Firm. McGraw-Hill, Madison.

[11] Deng, Z., Lu, Y., Wei, K.K. and Zhang, J. (2009) Understanding Customer Satisfaction and Loyalty: An Empirical Study of Mobile Instant Messages in China. International Journal of Information Management, 30, 289-300.

[12] Gerpott, T.J., Rams, W. and Schindler, A. (2001) Customer Retention, Loyalty and Satisfaction in the German Mobile Cellular Telecommunications Market. Telecommunications Policy, 25, 249-269.

[13] Doney, P.M. and Cannon, J.P. (1997) An Examination of the Nature of Trust in Buyer-Seller Relationships. Journal of Marketing, 61, 35-51. http://dx.doi.org/10.2307/1251829 
[14] Rauyruen, P. and Miller, K.E. (2007) Relationship Quality as a Predictor of B2B Customer Loyalty. Journal of Business Research, 60, 21-31.

[15] Singh, J. and Sirdeshmukh, D. (2000) Agency and Trust Mechanisms in Consumer Satisfaction and Loyalty Judgments. Journal of the Academy of Marketing Science, 28, 150-167.

[16] Reichheld, F.F. and Schefter, P. (2000) E-Loyalty: Your Secret Weapon on the Web.

[17] Palvia, P. (2009) The Role of Trust in e-Commerce Relational Exchange: A Unified Model. Information \& Management, 46, 213-220.

[18] Gundlach, G., Achrol, R. and Mentzer, J. (1995) The Structure of Commitment in Exchange. Journal of Marketing, 59, 78-92.

[19] Gomez, M.I., McLaughlin, E.W. and Wittink, D.R. (2004) Customer Satisfaction and Retail Sales Performance: An Empirical Investigation. Journal of Retailing, 80, 265-278.

[20] Bansal, H., Irving, G. and Taylor, S. (2004) A Three-Component Model of Customer Commitment to Service Providers. Journal of the Academy of Marketing Science, 32, 234-250.

[21] Athanasopoulou, P. (2009) Relationship Quality: A Critical Literature Review and Research Agenda. European Journal of Marketing, 43, 583-610.

[22] Szymanski, D.M. and Henard, D.H. (2001) Customer Satisfaction: A Meta-Analysis of the Empirical Evidence. Journal of the Academy of Marketing Science, 29, 16-35.

[23] Anderson, E.W. and Sullivan, M.W. (1993) The Antecedents and Consequences of Customer Satisfaction for Firms. Marketing Science, 12, 125-143.

[24] Gruen, T., Summers, J. and Acito, F. (2000) Relationship Marketing Activities, Commitment and Membership Behaviors in Professional Associations. Journal of Marketing, 64, 34-49.

[25] Anderson, E.W., Fornell, C. and Lehmann, D.R. (1994) Customer Satisfaction, Market Share and Profitability: Findings from Sweden. Journal of Marketing, 58, 53-66.

[26] Parasuraman, A., Zeithaml, V.A. and Berry, L.L. (1988) SERVQUAL: A Multiple-Item Scale for Measuring Consumer Perceptions of Service Quality. Journal of Retailing, 64, 12-40.

[27] Gronroos, C. (1984) A Service Quality Model and Its Marketing Implications. European Journal of Marketing, 18, 3644.

[28] Parasuraman, A., Zeithaml, V.A. and Berry, L.L. (1985) A Conceptual Model of Service Quality and Its Implications for Further Research. Journal of Marketing, 49, 41-50.

[29] Brady, M.K. and Cronin Jr., J.J. (2001) Some New Thoughts on Conceptualizing Perceived Service Quality: A Hierarchical Approach. Journal of Marketing, 65, 34-49. http://dx.doi.org/10.1509/jmkg.65.3.34.18334

[30] Hsieh, Y.-C. and Hiang, S.-T. (2004) A Study of the Impacts of Service Quality. International Journal of Business Studies, 15, 83-98.

[31] Herrmann, A., Huber, F. and Braunstein, C. (2000) Market-Driven Product and Service Design: Bridging the Gap between Customer Needs, Quality Management, and Customer Satisfaction. International Journal of Production Economics, 66, 77-96.

[32] Caceres, R.C. and Paparoidamis, N.G. (2007) Service Quality, Relationship Satisfaction, Trust, Commitment and Business-to-Business Loyalty. European Journal of Marketing, 41, 836-867.

[33] Jih, W.-J., Lee, S.-F. and Tsai, Y.-C. (2007) Effects of Service Quality and Shared Value on Trust and Commitment: An Empirical Study of 3Cs Product Customers in Taiwan. 